\title{
Different Reality? Generations' and Religious Groups' Views of Spirituality Policies in the Workplace
}

\author{
Patricia Jolliffe $^{1}$ (D) Scott Foster ${ }^{1}$
}

Received: 15 October 2019/Accepted: 15 September 2021 / Published online: 15 October 2021

(C) The Author(s) 2021

\begin{abstract}
Over the past 20 years, there has been considerable expansion, particularly spirituality theory in the workplace. Simultaneously, there has been a growth of research, most especially in practitioner publication into generational differences. The study's context is human resource (HR) policy and procedures in the workplace. Through this prism, generational perspectives and religious theory are compared and scrutinised within the United Kingdom. Two major religious groups (Muslim and Christian) and three-generational categories (Millennials, Generation X, and Baby Boomers) were selected to explore different attitudes, with participants identifying as belonging to religious groups outside of these two major religions, categorised as 'Other.' This study adopts a quantitative approach, with questionnaires gathering employees' perceptions of spirituality policy within their place of work. Although the study found differences in expectations between the religious groups and between the three generations, there is greater homogeneity than a difference in that the results provide limited support for workplace spirituality. Indeed, the study raises more questions than answers. The study uncovered areas ripe for informed debate around personal values, generations, and spirituality in the workplace. This is a relatively new research area, and our findings are in line with others that suggest that employee spiritual well-being is both underresearched and underexplored by organisations. Changing the current intransigence around the place of spirituality is overdue.
\end{abstract}

Keywords Spirituality $\cdot$ Generational $\cdot$ Religion

\section{Introduction}

Despite the increased worldwide interest in workplace spirituality (Bell \& Burack, 2001; Bhatia \& Arora, 2017; Palframan \& Lancaster, 2019; Saks, 2011; Sedikides, 2010; Wagner-Marsh \& Conley, 1999), it is still deemed to be an emerging field with little practical support in organisations for employees who self-ascribe as being spiritual (Miller \& Ewest, 2013). According to Bodia and Ali (2012) research, workplace spirituality helps employees realise they have a sense of community and purpose in work, by moving beyond their economic self-interest (McGhee, 2019). In

Patricia Jolliffe

p.a.jolliffe@ljmu.ac.uk

Scott Foster

s.foster@1jmu.ac.uk

1 Liverpool John Moores University, Clarence Street, Liverpool L3 5UX, UK other words, spirituality can help employees overcome difficult challenges in the work environment and produce an ethical work climate, where employees care for the well-being of others (Wimbush \& Shepard, 1994).

It is widely recognised that individuals from different religious groups (Bhatia \& Arora, 2017; Forstenlechner \& Al-Waqfi, 2010) can hold dissimilar beliefs, as well as opposing values (Robinson, 2009), which can present challenges when managing in the workplace. Nonetheless, religious diversity is a relatively commonplace area in Human Resource (HR) and is considered beneficial for society as a whole (Woolf Institute, 2020). Human Resource policies reflect organisational values and provide guiding principles, and are used to resolve problems, whilst also influencing positive social change. The term 'spirituality' refers to the raison d'être of an individual's existence, the meaning that a person ascribes to life providing a sense of belonging and hope, as well as assisting with coping strategies and a sense of control (Royal College of 
Psychiatrists, 2014). According to Amin et al., (2021), workplace spirituality equally associates with personal values.

Researchers have identified five workplace generations (Knight, 2014; Milliman et al., 2003) who, according to generational theory, differ in expectations and values (Manneheim, 1936). For example, Bengtson (2014), argues that Millennials are less interested than Baby Boomers in religion. Whilst singular studies on generational theory and workplace spirituality exist, the authors identified a gap in the literature concerning workplace spirituality when both generational and religious groups are combined. This research addresses this gap by exploring generational differences by the two major religions-Christianity and Muslim-concerning workplace policies and procedures to support an individual's spirituality, thus mirroring the groups utilised in the Woolf (2020) 'How we Get Along' study.

The research sample comprised 683 employees from UK private-sector retail and a third-sector organisation, of which 571 self-ascribed as Christian or Muslim, whilst 112 self-ascribed to six different religious or non-religious groupings. Owing to the number of and subsequent statistical data differences, the study focussed on Christian and Muslim groups. Overall, the results mirrored the extant literature, with most employees stating they felt that there were limited policies and procedures to support their spiritual needs (Shinde \& Fleck, 2015; Zohar \& Marshall, 2004)

Neal (2018) highlights how baby boomers spiritual needs led to an increased interest in workplace spirituality. Despite this influence there is a gap in the research, and thus this article contributes to evaluating generational theory and spirituality by examining expectations by religious grouping (Muslim and Christian) and by generation (Generation X, Millennials, and Baby Boomers). Furthermore, it contributes to the small corpus of empirical work on spirituality and the even smaller body of research combining both generational and religious groupings in the UK. workplace. Moreover, the study supports Mitchell and Beninger's (2015) call for organisations to provide more significant guidance relating to spirituality.

\section{Literature Review}

The purpose of this study is to extend the religious and generational literature. Initially, the history of spirituality is explored critically, along with associated concepts of values in the workplace, generational differences and policy and practice, which leads to the methods deployed to evaluate these concepts.

\section{Workplace Spirituality and Values}

Research into spirituality is often associated with religion (Cavanagh, 1999) and has gained greater prominence since the 'enlightenment period' (Bauman \& Haugaard, 2008). There are two viewpoints of spirituality: a religious phenomenon or a humanist phenomenon, with little religious connotations (Fisher, 2011). The humanistic view of spirituality may include compassion, such as deep reflection, enjoying nature, and poetry. It may also comprise maintaining stable family relationships and friendships.

Owing to the topic's considerable subjectivity (Fry, 2003; Mukherjee et al. 2016), studies on workplace spirituality have resulted in various terms of emphasis, foci, components, and analysis levels, although the concept remains undertheorised (Karakas, 2010). One of the critical challenges of workplace spirituality and religion is that these concepts are separate but similar (Mitroff \& Denton, 1999). Whilst acknowledging the field's breadth, Neal (2018) highlights the similarity in her extensive work on faith and spirituality in the workplace. Miller and Ewest (2015) produced a faith and organisational framework for an employee's spiritual and religious needs in the workplace, using the term'faith' to encompass spirituality and religion. Like both Neal et al. (1999) and Miller and Ewest (2015), this paper uses'spirituality' and'religion' interchangeably whilst noting differences. We understand workplace spirituality from the preferred definition of Neal (2018) that recognises employees have an inner life that is sustained by meaningful work in the context of a community. Choices of terminology are challenging, particularly in a field where there is no universally accepted definition of this complex collection of phenomena (Ali, 2010), and the process of conceptualisation has, thus far, produced tentative definitions of the term. Indeed Kourie (2006) suggests that all individuals express spirituality, whether nihilistic, materialistic, humanistic, or religious.

There is little doubt that workplace spirituality is receiving attention (Young, 2020) with an awareness of how an environment conducive to self-expression and inner purpose can enhance capability and raise organisational 'consciousness' (Palframan \& Lancaster, 2019). However, we also know that self-expression is'tolerated' (Digh, 1999), that there is tension between the expression of religious identities (Haldorai et al., 2020), and that there is limited evidence of impact on management practice in the workplace (Driscoll, 2019) with Sedikides (2010) arguing that religion within the workplace is still not given sufficient attention. The rise of interest in the Islamic faith throughout the media (Badrinarayanan \& Madhavaram, 2008) has also accelerated debate surrounding spirituality and work, notably the association between religion and 
management (Cowling, 2013). Woolf (2020) calls for organisations to create integration strategies that will encourage greater self-expression by ethnic and religious groups to achieve 'social mixing', whilst Young (2020) argues for further research on the subject. In conclusion, the literature is fragmented and dominated by speculative discussion, an American perspective, and a marked lack of empirical data, especially quantitative research (Ali, 2010; Khaled et al., 2012; Palframan \& Lancaster, 2019). However, there is a need to meet workers' spiritual needs and values with wider potential societal benefits (Woolf 2020).

The universalistic nature of the content and structure of values is well established (Sverdlik, 2020), with the concept of personal values, defined as goals that act as guiding principles in people's lives. These are quite broad and overarching, such as Schwartz's et al. (2012) model that includes nineteen types of value. One particularly relevant value of Schwartz's et al. (2012) is conformity with rules and obligations in order to recognise the maintenance of social order through compliance with institutional expectations. Organisational values, albeit less explored (Arieli et al., 2020), in contrast to personal values that are specific to an individual, comprise many values that make up a 'system' (Bourne \& Jenkins, 2013). There is a relationship between organisational values and behaviour as values are assumed to guide behaviour (Giacomin \& Jones, 2021).

Furthermore, Vveinhardt (2017) espouses the value of a dynamic, interactive development process in achieving organisational and personal value congruence. Organisations can create alignment between their employee's personal and organisational values through organisational policies and procedures. Although there can be differences between employer expectations and employee needs (Sauerwein, 2017), this can be addressed by encouraging employees to integrate personal spiritual values within the workplace. In endeavouring to align personal and organisational values, both parties can learn to move beyond themselves and aspire for more extraordinary things, giving meaning and purpose to their lives at work. Organisations that create this wider perspective that embody, rather than explains, workplace spirituality, can assist employees in moving beyond self-interest, to attain a higher purposeful position.

Research by Iqbal and Hassan (2016) reviewed the alignment between organisational policy and personal values. The findings suggest that workplace spirituality can provide a conduit between an individual's values and the organisation's purpose. Organisational values are related to the notion that an individual's goal extend beyond the person, to contribute to the wider community. Workplace spirituality motivates employees to work with integrity and purpose that is beneficial to others, beyond merely doing a job. Employees aspire to work within an organisation that has a heightened sense of ethics or integrity, and which aims to make a contribution to both employees and their community's welfare (Dhingra, et al., 2021). Furthermore, evidence for the essential nature of values is apparent in the Chartered Institute of Personnel and Development's (CIPD) ethically driven professional map (CIPD, 2020), which educates, and guides HR practice and is punctuated with the concept of 'values'. Moreover, Dhingra et al., alerts organisations to expect increased staff turnover if they fail to heed the values dimension, whilst Haldorai et al. (2020) highlights the financial penalties of deviant behaviour, even as expressing the potential mediating role of workplace spirituality.

There is a distinct synergy between workplace spirituality and individual values, which serve as a guiding principle to personal practice (Farmer et al., 2019), whilst organisational values are enabled through organisational policy and procedure. The literature has focussed on the benefits of a positive relationship for workplace spirituality values but also highlighted the need for compliance to maintain social norms. Although deviant practices are apparent, there is also a lack of clarity as to employees' perceptions when personal values and organisational procedure clash. Thus, the perceptions of UK employees were sought, from differing religious and generational backgrounds, to further explore their reactions when personal values failed to align with those at work. This endeavour led to the first hypothesis.

H1 There is no difference between the generations and religious groupings compliance to company procedures and their personal values.

\section{Generational Differences}

A seminal Generational theory, developed by Manneheim (1936), suggests attitudinal differences between generations. Faragher (2016) and Urick et al. (2016), however, argue that Manneheim's cohort-based approach is outdated owing to variations in the methodologies utilised. These later works advocate a sociology-based alternative, whilst Lyons and LeBlanc (2019) propose a generational identity approach, which adopts a historical focus. This critical analysis recognises that intergenerational stereotyping, with its inherent criticism (see Perry et al., 2013). However, there remains a lack of universally agreed on agerange intervals. Despite the forgiving's, the cohort approach is cited by Neal (2018) as a significant factor in the emergence of workplace spirituality and is commonplace in such comparative quantitative research. Thus, the authors chose to adopt the cohort approach. Schroer (2015) identifies Baby Boomers as those born between the end of 
World War II and the mid-1960s, with Generation X embracing those born between 1966 and 1976. However, Twenge et al., (2015) suggest that Generation X ranges from 1965 to 1979 . Millennials as identified as being born between 1977 and 1994 (Schroer, 2015), whilst the Pew Research Center (2015) argues for 1981 to 1997. Despite discrepancies, it is asserted that Millennials constitute 50 per cent of the worldwide workforce, with the expectation of this increasing to around 75 per cent by 2025 (Deloitte, 2014)

This study focuses on three of the five generations: Baby Boomers, Generation X, and Millennials, with the conceptual areas of: work values, attitudes, and expectations (Benson \& Brown, 2011) providing a specific focus. Before identifying the differences in the generations, it is of note that intra-generational differences can exist for gender and work experience (Weber \& Elm, 2018). The Chartered Institute of Personnel and Development (2015a) highlighted the value of trust and recognition for young people compared with the flexibility required by older workers. Some researchers have gone further to suggest that Millennials are quite different from previous generations (Gong et al., 2018; Kibui et al., 2014) and represent the best-performing generation in history (Tulgan, 2011). As a corollary, Millennials have been identified as being more likely to express dissatisfaction with their work and experience higher levels of turnover, than other generations (Brown et al., 2015); which ascribes high expectations to them. Conversely, research findings portray Millennials as being lazy, over-confident, unprofessional and unethical (Kumar, 2014), and primarily motivated by financial gain (Barkhuizen, 2014). Regarding personal value orientation, Weber (2017) found that almost half of the Millennials emphasised the value of Personal Competence and concluded that Millennials were 'more focussed on themselves' (ibid, 527), placing a greater emphasis on competency values than social and ethical orientation. This finding is countered to Gong et al., (2018), who identified a sense of service or dedication to a cause as a significant factor for Millennials.

Conversely, Baby Boomers are considered more competitive (Lancaster, 2003) and prepared to work long hours to achieve success (Eisner, 2005). Furthermore, Benson and Brown (2011) found that they displayed greater job satisfaction and were less likely to quit than Generation X. However, Wallace' (2006) found no significant difference between levels of commitment to daily work of Baby Boomers and Generation X. Notwithstanding these differences, Urick et al. (2016) concluded that much of the debate surrounding generational differences is perpetuated by stereotypes, which can exacerbate conflict.

Various studies have researched religious belief in relation to generational differences, which lays the ground for this study (Finn \& Donovon, 2013; Pew Research Center, 2010). There is evidence that Millennials are less 'religious' than other generations (Bengtson, 2014) and have a lower propensity to identify with specific religious groups. Moreover, a large-scale longitudinal study by Twenge et al. (2015) found not only a lower religious orientation, but a tendency towards secularism, which associates with the Millennials apparent interest in spirituality, along with the desire to experience meaningful work (Glass, 2007), and make a positive impact (Jenkin, 2015; Petrucelli, 2017). Conversely, Ellor and McFadden (2011) found that Baby Boomers expressed a wish to grow in their faith and that this provided a source of meaning, although in diverse ways. In a 35-year longitudinal study Bengtson et al. (2014) found that greater attention to religion amongst (older) Baby Boomers. The study also found variations in socialisation experiences of different generational groups varied. with the young demonstrating significant leanings towards secularisation, a finding equally supported by Twenge et al., (2015).

\section{Spiritual Policy, Procedures, and Practice}

The growth of globalisation, fuelled by neoliberalism and (in the UK) a free-market economy, has increased pressures on organisations to influence positive social change, frequently enacted through HR policy and practice (Ali, 2010). HR policies serve as a guide for practice and purport to reflect fundamental principles and organisational values, with these being embedded within spirituality. Yet research suggests that few organisations have a spiritual policy (Bodia \& Ali, 2012), despite employees self-ascribe to the phenomenon (Dahlvig \& Longman, 2016). Further, where traditional management approaches have addressed spirituality in the workplace, there is a tendency for these to have underperformed (Jurkiewicz \& Giacalone, 2004). Although the right to freedom of religion exists in the UK and is regulated through the UK Human Rights Act (1998), few organisations have policies that address religion specifically, preferring to follow the liberal diversity route of embedding religion with others (potential) discriminators. The UK Equality Act (2010) enables organisations to promote equality through their policies (ACAS, 2014), which can incorporate a reference to religion or belief in the workplace. In this way, spirituality policies can be included within organisational policies (Mir et al., 2019).

Concerning spiritual policies, Miller and Ewest (2015) propose an organisational framework with four modalities: faith-avoiding, faith-based, faith-safe, and faith-friendly. The organisational framework reflects management's attitude as to whether they reject or embrace faith at work. The authors acknowledge that the first three modalities share 
commonalities to other frameworks, with the fourth adding a distinctive holistic dimension. Faith-avoiding is adopted by organisations that seek to suppress personal or communal expressions of faith, religion, or spirituality (Lund et al., 2003), which is considered an adversarial position (Giacalone \& Jurkiewicz, 2010). In contrast, a faith-based approach recognises one faith (religious or spiritual) tradition; typically, this approach is embedded in the culture created by founding members or in the historical structure and is intertwined in the organisation's mission statements. The compliant faith-safe modality adheres to minimum legislative requirements and whilst it'tolerates' employees' interests in faith, it goes no further. The final faith-friendly modality adopts a more holistic perspective, approach that proactively encourages faith manifestations at work. Miller and Ewest's (2015) research is of particular relevance to this study. Their framework is conceptual, rather than empirical, with little evidence of organisations proactively implementing the faith-friendly approach.

The ambiguous and highly nuanced nature of spirituality confounds managers, employees and researchers (Lund et al., 2003; Richards et al., 2009). Forstenlecher and AlWagfi's (2010) reported that an employee overheard the owner commenting on two kinds of Muslims within the organisation; those who are integrated with their peers, get drunk and eat everything at parties and those that are considered anti-social. From this management's perspective, a 'good' Muslim employee is incompatible with being a 'good' Muslim. Thus, managing and integrating spirituality into the workplace is complex. Further confusion can be generated though employees following the same religion exhibiting significant differences in how they observe and express their beliefs (Madden, 2015). For example, Muslim football/soccer players in the English Premier League have demonstrated differing perspectives on match day fasting during Ramadan (Cowling, 2013). In a work context, evidence of discrimination and unfair management practice from a large-scale study by the Equality and Human Rights Commission call for better workplace guidance (Mitchell \& Beninger, 2015).

Although the overall concept is ambiguous, workplace spirituality (and inner life) can sustain meaningful work. In practice, the literature illuminates how spiritual self-expression can cause tension, and is 'tolerated' dependent upon the personal perspective. Responding to Mitchell and Beninger's (2015) call for clearer guidance and to the possibility of accrued benefits from spiritual policies and procedures that reflect personal values (to sustain initiatives and provide a guiding light for employees practice), this study sought to identify the extent to which employees are aware of existing policies and the clarity of these through Hypothesis 2:
H2 The generational and religious groupings are aware of the provision and clarity of their organisation's spirituality policies and procedures.

Buss (2019) illuminates how specific organisations and Chief Executive Officer's (CEO), can publicly share how spirituality informs their work practice. Examples include Hubert Joly (Best Buy's former Chairman and CEO), who ascribes to both a purpose for all and social impact (Simpson, 2020); Nathan Sheets (CEO of Nature Nate's), who asserts that faith is integral to the workplace, citing Millennial's preference for 'authenticity and transparency' (Buss, 2019) and, finally, Walmart's CEO, Doug McMillon, who communicates openly about his Christian beliefs. Spiritual practice can equally be reflected in the way organisations reward behaviours, such as caring and being supportive of others, or simply adopting a genuinely authentic stance (Dewar et al., 2019). In terms of practice, the Chartered Institute of Personnel and Development's recent professional map (CIPD, 2020) urges HR professionals to communicate the meaning and purpose of work to employees. Whilst Abdelgawad and Zahra (2020) demonstrates the benefits of religious identity to the organisation, willing to connect to a diverse set of other organisations who share the same values.

In adopting partial links to spirituality and the generational cohort approach (Neal, 2018), this study sought to identify perceived differences in values, attitudes and expectations (particularly in respect of religion) held by respondents. Baby boomers are perceived as drivers of workplace spirituality, in that they aspire to 'live out their purpose' (Neal (2018, p. 12) at work; however, a wider perspective was adopted. The literature, including the UK HR professional body and younger generations, affirms workers' desire for meaningful (Amin, et al., 2021; Dhingra, et al., 2021; You et al., 2021), and impactful work (Jenkin, 2015; Petrucelli, 2017). In line with these aspirations, this study sought to identify the reality of these desires in practice through Hypothesis 3:

H3 The generational and religious groupings are equally aware of how their organisation's spirituality policy and procedures influence their day-to-day work practice.

\section{Methods}

The current survey aimed to examine how respondents perceived spirituality is managed in the workplace, with a specific focus on policies and procedures. The sample was drawn two UK organisations: a multi-national Retail organisation and a Housing organisation, with both having ethnically diverse workforces. Data were obtained from managers and employees, whose organisations comprised 
Table 1 Original Questionnaire

\section{SECTION A}

In completing this questionnaire, you are confirming that you have read and understood the information provided regarding the purpose of this study and agree to participate.

\section{Your Beliefs}

$\square$ Please tick your answer...

01 My personal convictions are the most important thing

02 Following the rules is the most important thing

03 I feel very satisfied by imagining a radical vision of the future

04 I very much like holding fast to my own, personal values and belief

05 I very much like forming my own rationale and interpretation of why bad things happened

Work and You

06 Working and doing something good for the afterlife is what matters most

\begin{tabular}{|c|c|c|c|c|c|c|}
\hline \multirow[t]{2}{*}{07} & \multirow[t]{2}{*}{ At work I aim to achieve my full potential as a person } & 1 & 2 & 3 & 4 & 5 \\
\hline & & $\square$ & $\square$ & $\square$ & $\square$ & $\square$ \\
\hline \multirow[t]{2}{*}{08} & \multirow[t]{2}{*}{ I enjoy working towards a better future } & 1 & 2 & 3 & 4 & 5 \\
\hline & & $\square$ & $\square$ & $\square$ & $\square$ & $\square$ \\
\hline \multirow[t]{2}{*}{09} & \multirow[t]{2}{*}{ It is important to me to work for an ethical organisation } & 1 & 2 & 3 & 4 & 5 \\
\hline & & $\square$ & $\square$ & $\square$ & $\square$ & $\square$ \\
\hline \multirow[t]{2}{*}{10} & \multirow{2}{*}{$\begin{array}{l}\text { Being guided by one's conscience is what matters most not } \\
\text { spiritual beliefs }\end{array}$} & 1 & 2 & 3 & 4 & 5 \\
\hline & & $\square$ & $\square$ & $\square$ & $\square$ & $\square$ \\
\hline \multirow[t]{2}{*}{11} & \multirow[t]{2}{*}{ It is important to me that my work is interesting or meaningful } & 1 & 2 & 3 & 4 & 5 \\
\hline & & $\square$ & $\square$ & $\square$ & $\square$ & $\square$ \\
\hline
\end{tabular}


Table 1 continued

\begin{tabular}{|c|c|c|c|c|c|c|}
\hline \multirow[t]{2}{*}{12} & \multirow[t]{2}{*}{ The main aim for me at work is to earn a living } & 1 & 2 & 3 & 4 & 5 \\
\hline & & $\square$ & $\square$ & $\square$ & $\square$ & $\square$ \\
\hline \multirow[t]{2}{*}{13} & \multirow[t]{2}{*}{ Getting life's day to day tasks done is what matters most } & 1 & 2 & 3 & 4 & 5 \\
\hline & & $\square$ & $\square$ & $\square$ & $\square$ & $\square$ \\
\hline \multirow[t]{2}{*}{14} & \multirow[t]{2}{*}{ I aim to help or support others when at work } & 1 & 2 & 3 & 4 & 5 \\
\hline & & $\square$ & $\square$ & $\square$ & $\square$ & $\square$ \\
\hline \multirow[t]{2}{*}{15} & \multirow[t]{2}{*}{ Having a good working environment is important to me } & 1 & 2 & 3 & 4 & 5 \\
\hline & & $\square$ & $\square$ & $\square$ & $\square$ & $\square$ \\
\hline \multirow[t]{2}{*}{16} & \multirow{2}{*}{$\begin{array}{l}\text { I really enjoy the workplace because there is a good rapport } \\
\text { and relationship with co-workers }\end{array}$} & 1 & 2 & 3 & 4 & 5 \\
\hline & & $\square$ & $\square$ & $\square$ & $\square$ & $\square$ \\
\hline \multirow[t]{2}{*}{17} & \multirow{2}{*}{ I like to be able to be creative and use my initiative in my job } & 1 & 2 & 3 & 4 & 5 \\
\hline & & $\square$ & $\square$ & $\square$ & $\square$ & $\square$ \\
\hline \multirow[t]{3}{*}{18} & \multirow{3}{*}{$\begin{array}{l}\text { At work I am fully committed and focused physically and } \\
\text { mentally }\end{array}$} & 1 & 2 & 3 & 4 & 5 \\
\hline & & $\square$ & $\square$ & $\square$ & $\square$ & $\square$ \\
\hline & & 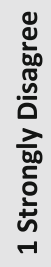 & 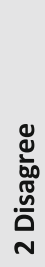 & 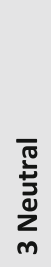 & 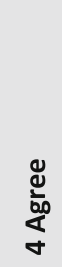 & 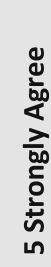 \\
\hline \multirow[t]{2}{*}{19} & \multirow[t]{2}{*}{ My religion is an important part of my life } & 1 & 2 & 3 & 4 & 5 \\
\hline & & $\square$ & $\square$ & $\square$ & $\square$ & $\square$ \\
\hline \multirow[t]{2}{*}{20} & \multirow[t]{2}{*}{ I consider myself a spiritual person } & 1 & 2 & 3 & 4 & 5 \\
\hline & & $\square$ & $\square$ & $\square$ & $\square$ & $\square$ \\
\hline \multirow[t]{2}{*}{21} & \multirow[t]{2}{*}{ I have heard of the term 'spirituality' } & 1 & 2 & 3 & 4 & 5 \\
\hline & & $\square$ & $\square$ & $\square$ & $\square$ & $\square$ \\
\hline \multirow[t]{2}{*}{22} & \multirow[t]{2}{*}{ I understand what the term 'spirituality' means } & 1 & 2 & 3 & 4 & 5 \\
\hline & & $\square$ & $\square$ & $\square$ & $\square$ & $\square$ \\
\hline \multirow[t]{2}{*}{23} & \multirow[t]{2}{*}{ My spirituality is an important part of my life } & 1 & 2 & 3 & 4 & 5 \\
\hline & & $\square$ & $\square$ & $\square$ & $\square$ & $\square$ \\
\hline \multirow[t]{2}{*}{24} & \multirow[t]{2}{*}{ I believe in God, a Deity or a Higher Power } & 1 & 2 & 3 & 4 & 5 \\
\hline & & $\square$ & $\square$ & $\square$ & $\square$ & $\square$ \\
\hline \multirow[t]{2}{*}{25} & I occasionally attend religious services & 1 & 2 & 3 & 4 & 5 \\
\hline & & $\square$ & $\square$ & $\square$ & $\square$ & $\square$ \\
\hline 26 & I regularly attend religious services & 1 & 2 & 3 & 4 & 5 \\
\hline & & $\square$ & $\square$ & $\square$ & $\square$ & $\square$ \\
\hline 27 & I occasionally pray or meditate & 1 & 2 & 3 & 4 & 5 \\
\hline & & $\square$ & $\square$ & $\square$ & $\square$ & $\square$ \\
\hline 28 & I often pray or meditate & 1 & 2 & 3 & 4 & 5 \\
\hline & & $\square$ & $\square$ & $\square$ & $\square$ & $\square$ \\
\hline 29 & I pray to get through the day & 1 & 2 & 3 & 4 & 5 \\
\hline & & $\square$ & $\square$ & $\square$ & $\square$ & $\square$ \\
\hline
\end{tabular}


Table 1 continued

\begin{tabular}{|c|c|c|c|c|c|c|}
\hline \multirow[t]{2}{*}{30} & \multirow[t]{2}{*}{ I pray to overcome adversity } & 1 & 2 & 3 & 4 & 5 \\
\hline & & $\square$ & $\square$ & $\square$ & $\square$ & $\square$ \\
\hline \multirow[t]{2}{*}{31} & \multirow[t]{2}{*}{ I pray to prepare myself for difficult situations } & 1 & 2 & 3 & 4 & 5 \\
\hline & & $\square$ & $\square$ & $\square$ & $\square$ & $\square$ \\
\hline \multirow[t]{2}{*}{32} & \multirow[t]{2}{*}{ I pray for co-workers who are going through difficult times } & 1 & 2 & 3 & 4 & 5 \\
\hline & & $\square$ & $\square$ & $\square$ & $\square$ & $\square$ \\
\hline \multirow[t]{2}{*}{33} & \multirow[t]{2}{*}{ I pray for guidance in making tough decisions } & 1 & 2 & 3 & 4 & 5 \\
\hline & & $\square$ & $\square$ & $\square$ & $\square$ & $\square$ \\
\hline \multirow[t]{2}{*}{34} & \multirow[t]{2}{*}{ I pray to cope with a bad tempered boss or co-workers } & 1 & 2 & 3 & 4 & 5 \\
\hline & & $\square$ & $\square$ & $\square$ & $\square$ & $\square$ \\
\hline \multirow[t]{2}{*}{35} & \multirow[t]{2}{*}{ I pray to give thanks for something good that has happened } & 1 & 2 & 3 & 4 & 5 \\
\hline & & $\square$ & $\square$ & $\square$ & $\square$ & $\square$ \\
\hline \multirow[t]{2}{*}{36} & \multirow[t]{2}{*}{ I pray to help with feelings of loneliness } & 1 & 2 & 3 & 4 & 5 \\
\hline & & $\square$ & $\square$ & $\square$ & $\square$ & $\square$ \\
\hline \multirow[t]{3}{*}{37} & \multirow[t]{3}{*}{ Spirituality is my own compass to guide my thoughts and beliefs } & 1 & 2 & 3 & 4 & 5 \\
\hline & & $\square$ & $\square$ & $\square$ & $\square$ & $\square$ \\
\hline & & 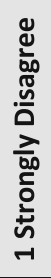 & 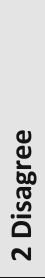 & 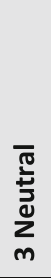 & 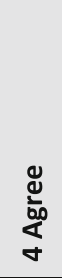 & 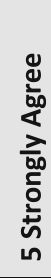 \\
\hline \multirow[t]{2}{*}{38} & \multirow[t]{2}{*}{ I have discussed my religion or spirituality with co-workers } & 1 & 2 & 3 & 4 & 5 \\
\hline & & $\square$ & $\square$ & $\square$ & $\square$ & $\square$ \\
\hline \multirow[t]{2}{*}{39} & \multirow[t]{2}{*}{ A co-worker has discussed their spirituality or religion with me } & 1 & 2 & 3 & 4 & 5 \\
\hline & & $\square$ & $\square$ & $\square$ & $\square$ & $\square$ \\
\hline \multirow[t]{2}{*}{40} & \multirow{2}{*}{$\begin{array}{l}\text { Religion is an appropriate topic for discussion within the } \\
\text { workplace }\end{array}$} & 1 & 2 & 3 & 4 & 5 \\
\hline & & $\square$ & $\square$ & $\square$ & $\square$ & $\square$ \\
\hline \multirow[t]{2}{*}{41} & \multirow{2}{*}{$\begin{array}{l}\text { Spirituality is an appropriate topic for discussion within the } \\
\text { workplace }\end{array}$} & 1 & 2 & 3 & 4 & 5 \\
\hline & & $\square$ & $\square$ & $\square$ & $\square$ & $\square$ \\
\hline \multirow[t]{2}{*}{42} & \multirow{2}{*}{$\begin{array}{l}\text { I feel comfortable discussing the topic of religion or spirituality } \\
\text { at work }\end{array}$} & 1 & 2 & 3 & 4 & 5 \\
\hline & & $\square$ & $\square$ & $\square$ & $\square$ & $\square$ \\
\hline \multirow[t]{2}{*}{43} & I feel comfortable discussing my own religion or spirituality at & 1 & 2 & 3 & 4 & 5 \\
\hline & work & $\square$ & $\square$ & $\square$ & $\square$ & $\square$ \\
\hline 44 & Religion or spirituality has a role within the workplace & 1 & 2 & 3 & 4 & 5 \\
\hline & & $\square$ & $\square$ & $\square$ & $\square$ & $\square$ \\
\hline 45 & I feel spiritually fulfilled at work & 1 & 2 & 3 & 4 & 5 \\
\hline & & $\square$ & $\square$ & $\square$ & $\square$ & $\square$ \\
\hline 46 & I feel that the level of spiritual fulfilment has a direct impact on & 1 & 2 & 3 & 4 & 5 \\
\hline & my performance at work & $\square$ & $\square$ & $\square$ & $\square$ & $\square$ \\
\hline 47 & Spirituality is a personal and individual matter and should not be & 1 & 2 & 3 & 4 & 5 \\
\hline & discussed or practised in the workplace & $\square$ & $\square$ & $\square$ & $\square$ & $\square$ \\
\hline & & 1 & 2 & 3 & 4 & 5 \\
\hline
\end{tabular}


Table 1 continued

48 The workplace is incompatible with spirituality

Policies and Procedures

49 My organisation has a clear policy on ethnical, cultural and ethnic spiritual diversity

$50 \quad$ My organisation has a clear policy on spirituality

51 I am aware of how my organisation's policies and procedures on spirituality influence work on a day-to-day basis

52 I am aware of a health or wellness programme within my workplace

53 I respect and comply with company procedures and rules whether they conform to my personal values and beliefs or not

54 I am aware of work/life balance programme within my workplace

55 I am aware of counselling or psychotherapy within my workplace

56 I am offered flexitime within my workplace to fulfil my spirituality

57 I am aware of prayer or meditation group within my workplace

\begin{tabular}{|c|c|c|c|c|}
\hline 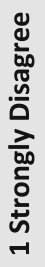 & 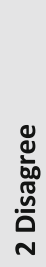 & $\begin{array}{l}\bar{\pi} \\
\frac{\pi}{3} \\
\bar{d} \\
z \\
m\end{array}$ & 芯 & 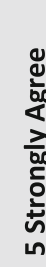 \\
\hline 1 & 2 & 3 & 4 & 5 \\
\hline$\square$ & $\square$ & $\square$ & $\square$ & $\square$ \\
\hline 1 & 2 & 3 & 4 & 5 \\
\hline$\square$ & $\square$ & $\square$ & $\square$ & $\square$ \\
\hline 1 & 2 & 3 & 4 & 5 \\
\hline$\square$ & $\square$ & $\square$ & $\square$ & $\square$ \\
\hline 1 & 2 & 3 & 4 & 5 \\
\hline$\square$ & $\square$ & $\square$ & $\square$ & $\square$ \\
\hline 1 & 2 & 3 & 4 & 5 \\
\hline$\square$ & $\square$ & $\square$ & $\square$ & $\square$ \\
\hline 1 & 2 & 3 & 4 & 5 \\
\hline$\square$ & $\square$ & $\square$ & $\square$ & $\square$ \\
\hline 1 & 2 & 3 & 4 & 5 \\
\hline$\square$ & $\square$ & $\square$ & $\square$ & $\square$ \\
\hline 1 & 2 & 3 & 4 & 5 \\
\hline$\square$ & $\square$ & $\square$ & $\square$ & $\square$ \\
\hline 1 & 2 & 3 & 4 & 5 \\
\hline$\square$ & $\square$ & $\square$ & $\square$ & $\square$ \\
\hline
\end{tabular}

\section{Management and Support}

\begin{tabular}{|c|c|c|c|c|c|c|}
\hline \multirow{3}{*}{58} & \multirow{3}{*}{$\begin{array}{l}\text { I feel that my manager should be aware of my spiritual } \\
\text { background and beliefs }\end{array}$} & & & \\
\hline & & 1 & 2 & 3 & 4 & 5 \\
\hline & & $\square$ & $\square$ & $\square$ & $\square$ & $\square$ \\
\hline \multirow[t]{2}{*}{59} & \multirow{2}{*}{$\begin{array}{l}\text { I believe that my manager is aware of my spiritual background } \\
\text { and beliefs }\end{array}$} & 1 & 2 & 3 & 4 & 5 \\
\hline & & $\square$ & $\square$ & $\square$ & $\square$ & $\square$ \\
\hline \multirow[t]{2}{*}{60} & \multirow[t]{2}{*}{ My manager understands my spiritual beliefs } & 1 & 2 & 3 & 4 & 5 \\
\hline & & $\square$ & $\square$ & $\square$ & $\square$ & $\square$ \\
\hline \multirow[t]{2}{*}{61} & \multirow{2}{*}{$\begin{array}{l}\text { I would feel comfortable discussing any issues I have relating to } \\
\text { work and spirituality with my manager }\end{array}$} & 1 & 2 & 3 & 4 & 5 \\
\hline & & $\square$ & $\square$ & $\square$ & $\square$ & $\square$ \\
\hline
\end{tabular}


Table 1 continued

\begin{tabular}{|c|c|c|c|c|c|c|}
\hline \multirow[t]{2}{*}{62} & \multirow{2}{*}{$\begin{array}{l}\text { I feel my manager would address any issues regarding } \\
\text { spirituality and work that arise. }\end{array}$} & 1 & 2 & 3 & 4 & 5 \\
\hline & & $\square$ & $\square$ & $\square$ & $\square$ & $\square$ \\
\hline \multirow[t]{2}{*}{63} & \multirow{2}{*}{$\begin{array}{l}\text { The organisation I work for does its best to support my } \\
\text { spirituality }\end{array}$} & 1 & 2 & 3 & 4 & 5 \\
\hline & & $\square$ & $\square$ & $\square$ & $\square$ & $\square$ \\
\hline \multirow[t]{2}{*}{64} & \multirow{2}{*}{$\begin{array}{l}\text { Organisations should be supportive of their employees' } \\
\text { spirituality }\end{array}$} & 1 & 2 & 3 & 4 & 5 \\
\hline & & $\square$ & $\square$ & $\square$ & $\square$ & $\square$ \\
\hline \multirow[t]{2}{*}{65} & \multirow[t]{2}{*}{ Management is not interested in the spirituality of its employees } & 1 & 2 & 3 & 4 & 5 \\
\hline & & $\square$ & $\square$ & $\square$ & $\square$ & $\square$ \\
\hline \multirow[t]{2}{*}{66} & \multirow{2}{*}{$\begin{array}{l}\text { Management is indifferent to any expression of spirituality in the } \\
\text { workplace }\end{array}$} & 1 & 2 & 3 & 4 & 5 \\
\hline & & $\square$ & $\square$ & $\square$ & $\square$ & $\square$ \\
\hline \multirow[t]{3}{*}{67} & \multirow{3}{*}{$\begin{array}{l}\text { Management is hostile to any expression of spirituality in the } \\
\text { workplace }\end{array}$} & 1 & 2 & 3 & 4 & 5 \\
\hline & & $\square$ & $\square$ & $\square$ & $\square$ & $\square$ \\
\hline & & 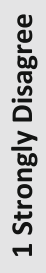 & 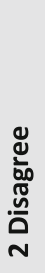 & 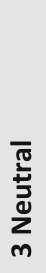 & 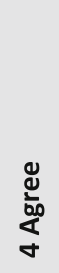 & 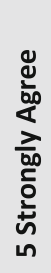 \\
\hline \multirow[t]{2}{*}{68} & \multirow[t]{2}{*}{ I feel spirituality or religion could be a source of conflict at work } & 1 & 2 & 3 & 4 & 5 \\
\hline & & $\square$ & $\square$ & $\square$ & $\square$ & $\square$ \\
\hline \multirow[t]{2}{*}{69} & \multirow[t]{2}{*}{ People irritate me when they ask me about my personal beliefs } & 1 & 2 & 3 & 4 & 5 \\
\hline & & $\square$ & $\square$ & $\square$ & $\square$ & $\square$ \\
\hline \multirow[t]{2}{*}{70} & \multirow{2}{*}{ I have witnessed conflict at work related to spirituality or religion } & 1 & 2 & 3 & 4 & 5 \\
\hline & & $\square$ & $\square$ & $\square$ & $\square$ & $\square$ \\
\hline \multirow[t]{2}{*}{71} & \multirow{2}{*}{$\begin{array}{l}\text { I have experienced conflict at work related to spirituality or } \\
\text { religion }\end{array}$} & 1 & 2 & 3 & 4 & 5 \\
\hline & & $\square$ & $\square$ & $\square$ & $\square$ & $\square$ \\
\hline \multirow[t]{2}{*}{72} & \multirow{2}{*}{$\begin{array}{l}\text { At times, I have been forced to compromise my personal beliefs } \\
\text { or values at work }\end{array}$} & 1 & 2 & 3 & 4 & 5 \\
\hline & & $\square$ & $\square$ & $\square$ & $\square$ & $\square$ \\
\hline \multirow[t]{2}{*}{73} & \multirow{2}{*}{$\begin{array}{l}\text { I have regularly been forced to compromise my personal beliefs } \\
\text { or values at work }\end{array}$} & 1 & 2 & 3 & 4 & 5 \\
\hline & & $\square$ & $\square$ & $\square$ & $\square$ & $\square$ \\
\hline \multirow[t]{4}{*}{74} & \multirow[t]{4}{*}{ I dislike conflict between people } & 1 & 2 & 3 & 4 & 5 \\
\hline & & $\square$ & $\square$ & $\square$ & $\square$ & $\square$ \\
\hline & & 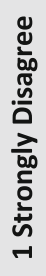 & 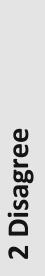 & $\begin{array}{l}\bar{\pi} \\
\frac{\pi}{2} \\
\frac{0}{2} \\
\sum_{m}\end{array}$ & 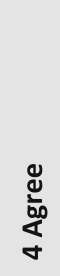 & 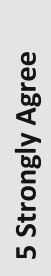 \\
\hline & & 1 & 2 & 3 & 4 & 5 \\
\hline
\end{tabular}


Table 1 continued

\begin{tabular}{|c|c|c|c|c|c|c|}
\hline 75 & I feel spiritually fulfilled at work & $\square$ & $\square$ & $\square$ & $\square$ & $\square$ \\
\hline \multirow[t]{2}{*}{76} & \multirow{2}{*}{$\begin{array}{l}\text { The attitudes or comments of co-workers impact upon my level } \\
\text { of spiritual fulfilment }\end{array}$} & 1 & 2 & 3 & 4 & 5 \\
\hline & & $\square$ & $\square$ & $\square$ & $\square$ & $\square$ \\
\hline \multirow[t]{2}{*}{77} & \multirow{2}{*}{$\begin{array}{l}\text { Management understanding of my spiritual beliefs enhances my } \\
\text { spiritual fulfilment }\end{array}$} & 1 & 2 & 3 & 4 & 5 \\
\hline & & $\square$ & $\square$ & $\square$ & $\square$ & ᄃ \\
\hline \multirow[t]{2}{*}{78} & \multirow{2}{*}{$\begin{array}{l}\text { The level of support and attitude from management is } \\
\text { detrimental to spiritual fulfilment }\end{array}$} & 1 & 2 & 3 & 4 & 5 \\
\hline & & $\square$ & $\square$ & $\square$ & $\square$ & $\square$ \\
\hline \multirow[t]{2}{*}{79} & \multirow{2}{*}{$\begin{array}{l}\text { The nature of my work and lack of time available prevent me } \\
\text { from fulfilling my spirituality }\end{array}$} & 1 & 2 & 3 & 4 & 5 \\
\hline & & $\square$ & $\square$ & $\square$ & $\square$ & ᄃ \\
\hline \multirow[t]{2}{*}{80} & \multirow{2}{*}{$\begin{array}{l}\text { The facilities available at work negatively affects my level of } \\
\text { spiritual fulfilment }\end{array}$} & 1 & 2 & 3 & 4 & 5 \\
\hline & & $\square$ & $\square$ & $\square$ & $\square$ & ᄃ \\
\hline
\end{tabular}

\section{SECTION B}

The following information will remain confidential and will not be used for any other purpose than to group the results - the questionnaire is anonymous and no individual will be identified.

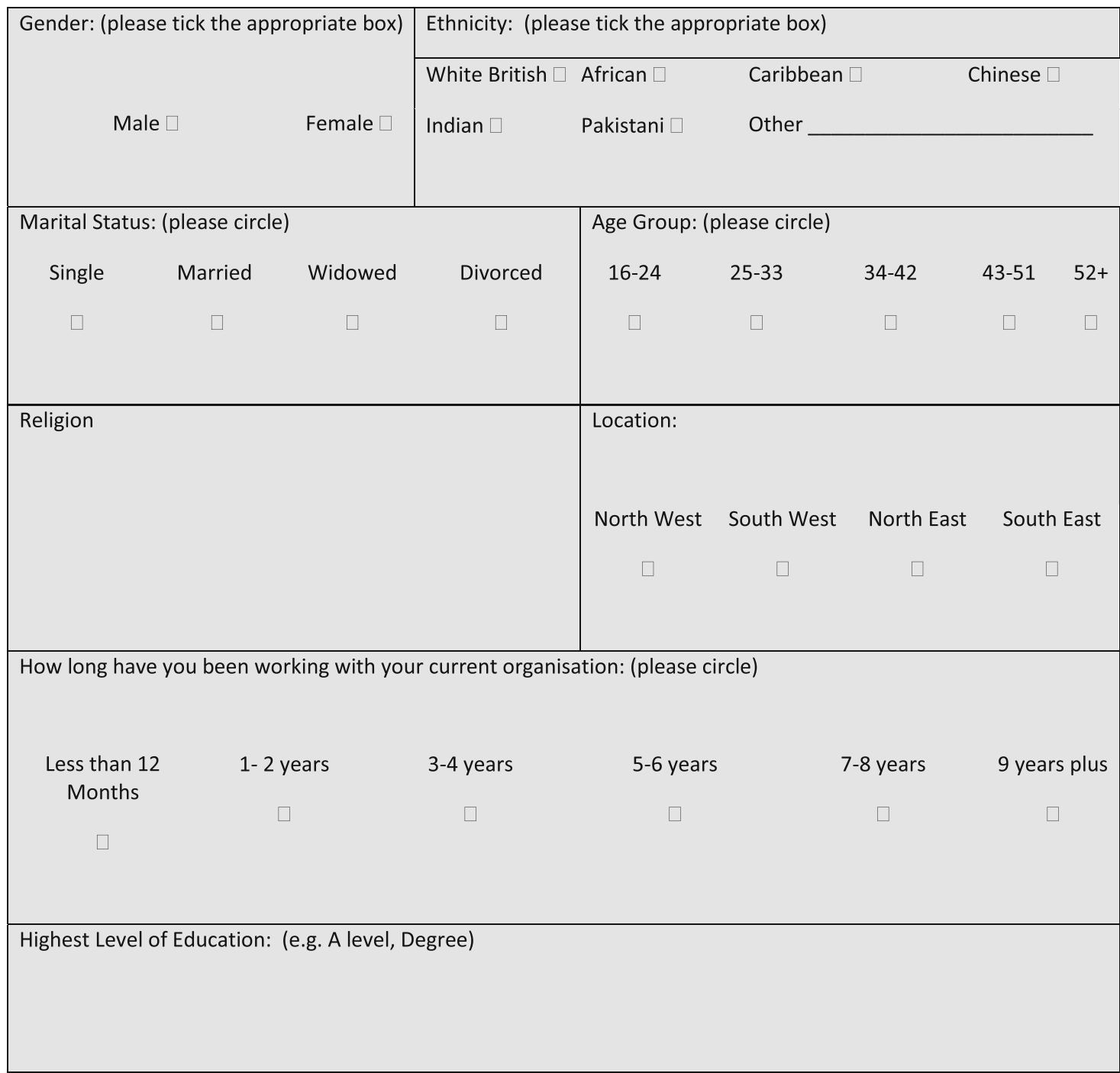

Thank you for your support and for taking the time to complete this questionnaire. 
55 stores and 812 employees from Retail, and 750 workers from Housing. For the retail organisation, questionnaires (Table 1) were despatched to General and Sales Managers, electronically, through internal email. For Housing, the Head of HR distributed printed copies through the internal post, along with sealed envelopes provided by the research team. The final questionnaire incorporated a five-point Likert-scale items ( $1=$ strongly disagree; $5=$ strongly agree).

In line with the study aim, each item in the questionnaire was derived from the literature, including previous research. The absence of a universal agreement surrounding spirituality exacerbated item choice. For example, whilst the link between spirituality and policy is identified in the literature (Forstenlechner \& Al-Waqfi, 2010; Zohar $\&$ Marshall, 2004), although there is the nuance that suggests that spirituality should be embedded within organisational policies and procedures. (Ali, 2010; Khaled et al., 2012). The following academic sources were drawn on in questionnaire and hypotheses design: Badrinarayanan \& Madhavaram, 2008; Forstenlechner \& Al-Waqfi, 2010; Jurkiewicz \& Giacalone, 2004; Morgan, 2005; Zohar \& Marshall, 2004.

A pilot study was undertaken, using thirty employees. Feedback highlighted the requirement for rewording of seven items, to aid clarity, particularly about consistency of the term spirituality. Vocabulary in three items on religion were considered to target those with specific religious beliefs, which omitted non-religious groups. religion. Pilot respondents suggested that a Likert scale of five points, rather than the original seven points, would assist clarity and ease of completion. The move to a five-point Likert scale is supported by Finstad (2010), who asserted that: "Participants in the 5-point scale condition were more likely than those presented with the 7-point scale to interpolate, i.e., attempt a response between two discrete values offered to them" (ibid, 104).

Regarding overall questionnaire layout, respondents observed that some subheadings created confusion, particularly within spirituality—heading were subsequently revised and reduced.

Following revisions, a second pilot study was undertaken, as well as the time taken to complete a questionnaire, which was in the region of fifteen minutes.
Respondents in the second pilot reported that the wording was easily understood. The value of conducting a pilot study has been stressed, particularly in terms of response rates and clarity of data, which can enhance reliability and suitability Bell et al. (2018).

After revisions, the final questionnaires were distributed to 1562 employees, with a response rate of $44 \%$ (683).

\section{Findings}

A Cronbach's alpha reliability-coefficient test returned a reliability score of 0.843 As this exceeds 0.70 , a high degree of internal consistency within the scaled data is assumed (Field, 2018), with data being amenable to parametric statistical analysis.

\section{Sample Profile: Gender, Age, and Religion}

The sample comprised of 385 from Retail and 298 from a Housing Association (683 responses), with $62.1 \%$ being men and $37.9 \%$ women. Of the 683 respondents, 173 were aged 20-24 years; 67 between 25-33 years; 79 from 34 to 42 years; 209 between 43 and 51 years, and 155 aged 52 years or older. In terms of religion, over $84 \%$ of the respondents identified as either Christian $(n=457,67 \%)$ or Muslim $(n=114,17 \%)$, with the remaining $16 \%(n=112)$ falling into different categories, which was subsequently labelled 'Other'. These included Agnostic, Atheist, Hindu, Jewish, Jehovah Witness, and Sikhs. The inclusion 'Other' in the analysis provides a more complete picture of spirituality and generational diversity for the study organisations. Analysis of the independent variable for age identified Millennials as being 1981 to 1997; Generation X as 1965 to 1980 and Baby Boomers up to mid-1960s. Table 2 outlines the perceptions of respondents by generational and religious categories.

The research instrument comprised six scaled items, designed to measure respondents' perceptions and awareness of organisational policies and procedures relating to spirituality. The Anova Statistical results for religion are presented in Table 3.
Table 2 Sample statistics: generational and religious categories

\begin{tabular}{llllll}
\hline & & Millennials & Generation X & Baby Boomers & Total \\
\hline \multirow{4}{*}{ Number of respondents } & Age categories & $20-42$ years & $43-51$ years & 52 years or older & \\
& Christians & 229 & 132 & 96 & 457 \\
& Muslims & 54 & 33 & 27 & 114 \\
Total & Other & 36 & 44 & 32 & 112 \\
& & 319 & 209 & 155 & 683 \\
\hline
\end{tabular}


Table 3 Analytical Findings (Anova) Summary of Muslim, Christian and 'Other' Perceptions of Organisational Policies and Procedures

\begin{tabular}{|c|c|c|c|}
\hline Variables & $\begin{array}{l}\text { Mean (Standard } \\
\text { Deviation) }\end{array}$ & Religion & $\begin{array}{l}\mathrm{P}- \\
\text { Value }\end{array}$ \\
\hline \multirow[t]{3}{*}{ My organisation has a clear policy on ethical, cultural, and ethnic spiritual diversity [H2] } & $1.26(1.41)$ & Muslim & .001 \\
\hline & $2.26(2.20)$ & Christian & .005 \\
\hline & $1.69(1.01)$ & Other & .069 \\
\hline \multirow[t]{3}{*}{ My organisation has a clear policy on spirituality [H2] } & $1.07(1.19)$ & Muslim & .000 \\
\hline & $1.25(2.10)$ & Christian & .000 \\
\hline & $1.31(.78)$ & Other & .016 \\
\hline \multirow{3}{*}{$\begin{array}{l}\text { I am aware of how my organisation's policies and procedures on spirituality influence work on a day-to- } \\
\text { day basis [H1] }\end{array}$} & $1.15(1.36)$ & Muslim & .004 \\
\hline & $2.11(1.56)$ & Christian & .003 \\
\hline & $2.46(.90)$ & Other & .263 \\
\hline \multirow[t]{3}{*}{ I am aware of a health or wellness programme within my workplace [H2] } & $3.10(1.15)$ & Muslim & .002 \\
\hline & $4.22(.69)$ & Christian & .011 \\
\hline & $3.16(1.14)$ & Other & .003 \\
\hline \multirow{3}{*}{$\begin{array}{l}\text { I respect and comply with company procedures and rules, whether or not they conform to my personal } \\
\text { values and beliefs [H1] }\end{array}$} & $2.22(1.46)$ & Muslim & .002 \\
\hline & $3.22(1.44)$ & Christian & .032 \\
\hline & $3.44(1.05)$ & Other & .778 \\
\hline \multirow[t]{3}{*}{ I am aware of a work-life balance programme within my workplace [H3] } & $1.14(.85)$ & Muslim & .003 \\
\hline & $2.11(2.10)$ & Christian & .001 \\
\hline & $1.33(1.61)$ & Other & .113 \\
\hline
\end{tabular}

A significantly notable finding showed that perceptions according to religion was not a major factor. Christian and Muslim respondents were broadly in agreement, on all six scaled items, with a trend towards 'disagree'.

The findings presented in Table 4 suggest that whilst the six statements were statistically significant $(p=\leq 0.05)$ from the Muslim and Christian groups; in the 'Other' religious category only two statements were significant. Overall, respondents disagreed that holding that the organisation provided policies and procedures relating to workplace spirituality. The most notable item related to "My organisation has a clear policy on ethical, cultural, and ethnic spiritual diversity" and "My organisation has a clear policy on spirituality," with Christian respondents returning means of 2.62 and 1.25, while Muslim respondents returned 1.36 and 1.09 ; the 'Other' category were 1.67 and 1.88 , respectively. The item with the greatest overall agreement concerned "I am aware of a health or wellness programme within my workplace" (4.11 Christian; 3.88 Muslim; 3.65 'Other').

Table 5 presents the Anova generational results for the six-scale items.

It terms of religion, Table 6 outlines statistically significant differences amongst the items for organisational policies and procedures in the workplace organisations. In terms of "My organisation has a clear policy on ethical, cultural, and ethnic spiritual diversity" Millennial Muslims and Baby Boomers returned lower means than Christian Millennials, Generation X and 'Other' (2.11, 2.45 and 1.22, respectively). With regards to "My organisation has a clear policy on spirituality", Muslim respondents of Generation X (1.17) and Muslim Millennials (1.22) returned lower means than Muslim Baby Boomers (1.79). Muslim, Christian and 'Other' group. Baby Boomers (1.11, 1.56 and 1.12 , respectively) disagreed more with the statement "I am aware of how my organisation's policies and procedures on spirituality influence work on a day-to-day basis" than did Millennials and Generation X. Muslims of all generations disagreed more with the statement "I respect and comply with company procedures and rules, whether or not they conform to my personal values and beliefs" than did their Christian counterparts. Further, when their personal values are challenged, Muslim Millennials and Generation $\mathrm{X}$ felt less inclined to conform to procedures and rules (2.34 and 2.14). Finally, Muslims of all generations returned a lower mean for "I am aware of a work-life balance programme within my workplace" than did all Christian and 'other' groups. The perceived disenchantment by Muslim Millennials and Generation X was marked (1.17 and 1.10, respectively) and in contrast to Christian Baby Boomers and 'Other' (3.45 and 2.10). 
Table 4 Summary of Muslim, Christian and 'other' Perceptions of Organisational Policies and Procedures

\begin{tabular}{|c|c|c|c|}
\hline Variables & $\begin{array}{l}\text { Mean (Standard } \\
\text { Deviation) }\end{array}$ & Religion & $\begin{array}{l}\mathrm{P}- \\
\text { Value }\end{array}$ \\
\hline \multirow[t]{3}{*}{ My organisation has a clear policy on ethical, cultural, and ethnic spiritual diversity } & $1.36(1.39)$ & Muslim & .002 \\
\hline & $2.62(2.11)$ & Christian & .004 \\
\hline & $1.67(1.00)$ & Other & .063 \\
\hline \multirow[t]{3}{*}{ My organisation has a clear policy on spirituality } & $1.09(1.11)$ & Muslim & .000 \\
\hline & $1.25(2.06)$ & Christian & .001 \\
\hline & $1.88(.78)$ & Other & .020 \\
\hline \multirow{3}{*}{$\begin{array}{l}\text { I am aware of how my organisation's policies and procedures on spirituality influence work on a day- } \\
\text { to-day basis }\end{array}$} & $1.88(1.11)$ & Muslim & .003 \\
\hline & $1.99(1.46)$ & Christian & .001 \\
\hline & $2.37(.92)$ & Other & .211 \\
\hline \multirow[t]{3}{*}{ I am aware of a health or wellness programme within my workplace } & $3.88(1.16)$ & Muslim & .001 \\
\hline & $4.11(.65)$ & Christian & .010 \\
\hline & $3.65(1.13)$ & Other & .002 \\
\hline \multirow{3}{*}{$\begin{array}{l}\text { I respect and comply with company procedures and rules, whether or not they conform to my personal } \\
\text { values and beliefs }\end{array}$} & $2.21(.46)$ & Muslim & .009 \\
\hline & $3.54(1.40)$ & Christian & .013 \\
\hline & $3.11(1.05)$ & Other & 657 \\
\hline \multirow[t]{3}{*}{ I am aware of a work-life balance programme within my workplace } & $1.19(.85)$ & Muslim & .002 \\
\hline & $2.88(2.19)$ & Christian & .005 \\
\hline & $1.11(1.59)$ & Other & .107 \\
\hline
\end{tabular}

Table 5 Descriptive statistics generational differences in policies and procedures

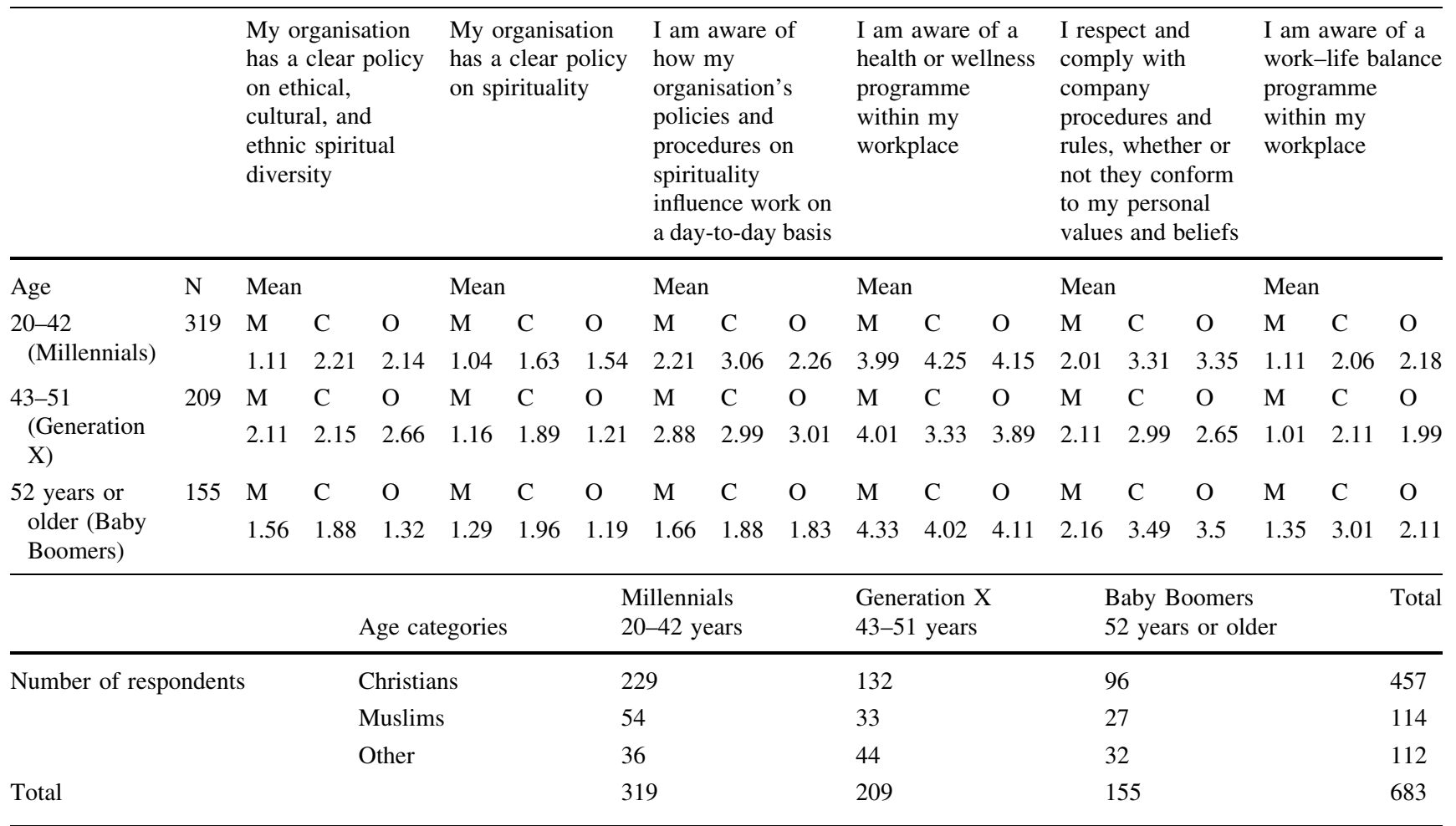

Key: $M$ Muslim; $M$ Christian; $O$ 'Other' groups Table 2: Generational and Religious Descriptive Statistics for Major Sample Categories 
Table 6 Descriptive Statistics for Generational Differences in Policies and Procedures

\begin{tabular}{|c|c|c|c|c|c|c|c|c|c|c|c|c|c|c|c|c|c|c|c|}
\hline \multirow{3}{*}{$\begin{array}{l}\text { Age } \\
20-42 \\
\text { (Millennials) }\end{array}$} & \multirow{3}{*}{$\begin{array}{l}\mathrm{N} \\
319\end{array}$} & \multicolumn{3}{|c|}{$\begin{array}{l}\text { My organisation } \\
\text { has a clear policy } \\
\text { on ethical, } \\
\text { cultural, and } \\
\text { ethnic spiritual } \\
\text { diversity }\end{array}$} & \multicolumn{3}{|c|}{$\begin{array}{l}\text { My organisation } \\
\text { has a clear policy } \\
\text { on spirituality }\end{array}$} & \multicolumn{3}{|c|}{$\begin{array}{l}\text { I am aware of } \\
\text { how my } \\
\text { organisation's } \\
\text { policies and } \\
\text { procedures on } \\
\text { spirituality } \\
\text { influence work on } \\
\text { a day-to-day basis }\end{array}$} & \multicolumn{3}{|c|}{$\begin{array}{l}\text { I am aware of a } \\
\text { health or wellness } \\
\text { programme } \\
\text { within my } \\
\text { workplace }\end{array}$} & \multicolumn{4}{|c|}{$\begin{array}{l}\text { I respect and comply } \\
\text { with company } \\
\text { procedures and rules, } \\
\text { whether or not they } \\
\text { conform to my } \\
\text { personal values and } \\
\text { beliefs }\end{array}$} & \multicolumn{2}{|c|}{$\begin{array}{l}\text { I am aware of } \\
\text { a work-life } \\
\text { balance } \\
\text { programme } \\
\text { within my } \\
\text { workplace }\end{array}$} \\
\hline & & \multicolumn{3}{|c|}{ Mean } & \multicolumn{3}{|c|}{ Mean } & \multicolumn{3}{|c|}{ Mean } & \multicolumn{3}{|c|}{ Mean } & \multicolumn{3}{|c|}{ Mean } & \multicolumn{3}{|c|}{ Mean } \\
\hline & & $\begin{array}{l}\mathrm{M} \\
1.23\end{array}$ & $\begin{array}{l}\text { C } \\
2.11\end{array}$ & $\begin{array}{l}\mathrm{O} \\
2.89\end{array}$ & $\begin{array}{l}\mathrm{M} \\
1.22\end{array}$ & $\begin{array}{l}\mathrm{C} \\
1.23\end{array}$ & $\begin{array}{l}\mathrm{O} \\
1.94\end{array}$ & $\begin{array}{l}\mathrm{M} \\
2.01\end{array}$ & $\begin{array}{l}\mathrm{C} \\
3.56\end{array}$ & $\begin{array}{l}\mathrm{O} \\
2.16\end{array}$ & $\begin{array}{l}\text { M } \\
2.99\end{array}$ & $\begin{array}{l}\mathrm{C} \\
4.23\end{array}$ & $\begin{array}{l}\mathrm{O} \\
5.00\end{array}$ & $\begin{array}{l}\mathrm{M} \\
2.34\end{array}$ & $\begin{array}{l}\mathrm{C} \\
2.31\end{array}$ & $\begin{array}{l}\mathrm{O} \\
3.30\end{array}$ & $\begin{array}{l}\mathrm{M} \\
1.17\end{array}$ & $\begin{array}{l}\text { C } \\
2.15\end{array}$ & \\
\hline $\begin{array}{l}43-51 \\
\text { (Generation } \\
\mathrm{X})\end{array}$ & 209 & $\begin{array}{l}\text { M } \\
2.10\end{array}$ & $\begin{array}{l}\mathrm{C} \\
2.45\end{array}$ & $\begin{array}{l}\mathrm{O} \\
2.11\end{array}$ & $\begin{array}{l}\mathrm{M} \\
1.17\end{array}$ & $\begin{array}{l}\mathrm{C} \\
1.19\end{array}$ & $\mathrm{O}$ & $\begin{array}{l}M \\
2.56\end{array}$ & $\begin{array}{l}\mathrm{C} \\
2.53\end{array}$ & $\begin{array}{l}\mathrm{O} \\
3.08\end{array}$ & $\begin{array}{l}\mathrm{M} \\
4.09\end{array}$ & $\begin{array}{l}\mathrm{C} \\
3.81\end{array}$ & $\begin{array}{l}\mathrm{O} \\
3.67\end{array}$ & $\begin{array}{l}M \\
2.14\end{array}$ & $\begin{array}{l}\mathrm{C} \\
3.01\end{array}$ & $\begin{array}{l}\mathrm{O} \\
2.35\end{array}$ & $\begin{array}{l}\mathrm{M} \\
1.10\end{array}$ & $\begin{array}{l}\text { C } \\
2.10\end{array}$ & \\
\hline $\begin{array}{l}52 \text { years or } \\
\text { older (Baby } \\
\text { Boomers) }\end{array}$ & 155 & $\begin{array}{l}\mathrm{M} \\
1.46\end{array}$ & $\begin{array}{l}\mathrm{C} \\
1.22\end{array}$ & $\begin{array}{l}\mathrm{O} \\
1.42\end{array}$ & $\begin{array}{l}\mathrm{M} \\
1.79\end{array}$ & $\begin{array}{l}\mathrm{C} \\
1.68\end{array}$ & $\begin{array}{l}\mathrm{O} \\
1.27\end{array}$ & $\begin{array}{l}\mathrm{M} \\
1.11\end{array}$ & $\begin{array}{l}\mathrm{C} \\
1.56\end{array}$ & $\begin{array}{l}\mathrm{O} \\
1.12\end{array}$ & $\begin{array}{l}\text { M } \\
4.11\end{array}$ & $\begin{array}{l}\text { C } \\
4.22\end{array}$ & $\begin{array}{l}\mathrm{O} \\
4.91\end{array}$ & $\begin{array}{l}M \\
2.17\end{array}$ & $\begin{array}{l}\text { C } \\
3.49\end{array}$ & $\begin{array}{l}\mathrm{O} \\
3.11\end{array}$ & $\begin{array}{l}\mathrm{M} \\
1.87\end{array}$ & $\begin{array}{l}\text { C } \\
3.45\end{array}$ & $\begin{array}{l}\mathrm{O} \\
2.10\end{array}$ \\
\hline
\end{tabular}

Key: $\mathrm{M}=$ Muslim; $\mathrm{C}=$ Christian; $\mathrm{O}=$ 'Other' groups

\section{Discussion and Hypothesis Tests Reflections}

Three hypotheses were tested concerning generations and religious groupings, knowledge, application and values of workplace spiritual policies and procedures.

Hypothesis 1 predicted that there would be no difference between the generational and religious groupings for compliance to organisational procedures and their personal values. The data show a perceived difference for generational and religious groups when personal values are challenged. Younger generation Muslim Millennials and Gen $X$ recognised the importance of personal values in their lives, contrary to Weber's (2017) finding, where Millennials reflected a tendency towards self. Furthermore, concerning company policy and procedures compliance, Muslims, particularly the Younger generations, were more likely to comply if a fit existed with their personal values. Equally, the results may indicate that Millennials and Generation $\mathrm{X}$ are more likely than Baby Boomers to live out their values in the workplace. This reminds us how religious groupings and generations spiritual values manifest differently and the need for organisational opportunity to understand and ignite this passion in the workplace. Notwithstanding this, one possible explanation is that the participants in this study identified as religious in orientation, which tends to associate with outward-looking values (Buss, 2019; McGhee, 2019). So, the literature reminds of the contribution of compliance to social order (Schwartz et al., 2012) and of the benefits of alignment such as, creativity (Shinde \& Fleck, 2015); employee engagement (CIPD, 2020); staff retention (Haldorai et al., 2020); motivated workers (Neal, 2018) and diversity tolerance
(Woolf, 2020) but also caution how the negative impact of a lack of alignment (Haldorai et al., 2020).

Hypothesis 2 proposes that generational and religious groupings are likely to have a strong awareness of the provision and clarity of the organisation's spirituality policies and procedures. As outlined in Table 3, the mean score of all groupings was universally low, suggesting that the study organisations do not have relevant policies, or they are unclear. However, the statistical analysis highlighted different perceptions between the religious and generational groups regarding clarity of policies. In terms of religious groups, Muslim employees were less in agreement than their Christian counterparts, which is in keeping with Forstenlechner and Al-Waqfi (2010) although contrary to Weller et al., (2001), which suggests that their spiritual needs are not fully supported. In terms of generations, Millennials and Gen X adopted a different perspective than Baby Boomers, although regardless of religious grouping, Gen $\mathrm{X}$ occupied an outlier position, in responding more negatively than the other generations for the provision of policy. The overall disagreement with this item suggests that employees' spiritual needs are not satisfactorily supported. The individual differences might be interpreted as Younger generations having greater expectations for clarity around fulfilling their spiritual needs in the workplace (Fry \& Slocum, 2008).

Furthermore, Hypothesis 3 predicted that generational and religious groupings would be equally likely to know how spirituality policy and procedures influence day-to-day work practice. However, findings suggest that the workers were unaware of how spiritual organisation's policies and procedures influence day-to-day practice. A statistically 
significant difference was found in how Baby Boomers and Millennials and Generation X understood the impact spirituality policies and procedures had on a day-to-day work situation. Indeed, when a misfit occurs the individual may challenge or deny a company policy that affronts their belief structure. Here, the consequence of spirituality not influencing practice can be perceived as a negative for employees. Overall, previous research (Dhingra et al., 2021; Neal, 2018; Palframan \& Lancaster, 2019) parallels this finding, in demonstrating a positive relationship between purpose and day-to-day work responsibilities. One way that organisations can achieve this is by creating an environment that is conducive to self-expression, with the message that employees want to live their purpose at work and find meaning in their daily work. When this connection is made, for example, employees can work more innovatively (Alexander et al., 2021).

\section{Conclusion}

The study sought to examine the generational and religious groupings perception of spiritual workplace policies and procedures and meet the call for further research in the area (Young, 2020). In adopting a critical stance, underpinned by theoretical concepts, the study provides statistical evidence which challenges existing stereotypes of religion and generational groupings. A gap has been identified between substantive organisational actions and employees' preferences. Indeed, it is apparent that organisations are hesitant in providing a positive response to the increasing presence of spirituality in the workplace, with self-expression being tolerated at most (Digh, 1999). The organisational process is, however, hampered by the vague and complicated nature of spirituality (Morgan, 2005, Sauerwein, 2017).

Historical attempts to define spirituality by how it is perceived from an organisational viewpoint have represented a considerable hurdle and complicated policymaking (Khaled et al., 2012). Nevertheless, in failing to develop spirituality policies, organisations are denying the positive values associated with meeting the core needs of various generations in the workplace (Mitchell \& Beninger, 2015). The specific theoretical and practical significance of this study are presented next.

\section{Theoretical Implications}

First, the research adds to the growing literature on workplace spirituality and differs from previous studies in that workplace spirituality is explored within generational and religious groupings. Moreover, the focus on context, policy, and procedure, further elevates the study. The additional findings that embrace organisational policy are set to encourage greater integration, belonging, and cohesion (Woolf 2020). Further, in elevating spirituality policies to create a broader societal impact (Amin et al., 2021).

Second, given the limited interest in religion, within the workplace (Twenge et al., 2015) the findings portray a novel story, wherein the intergenerational employees' selfascribed to a religious group. Thus, the study challenges the stereotypical notion that Baby Boomers hold a high interest in religion, with Younger generations being less inclined towards faith (Bengston 2015). Furthermore, spirituality was perceived to serve as an intrinsic guide for employee practice, particularly Younger generation Muslims. The concept is equally valued as a living, integral part of employees' lives, which adds support to generational theory. The study, therefore, provides an insight into the different generational attitudes across the UK's major religious groups.

Finally, spirituality, which relates to personal values (Amin et al., 2021), concerns the provision of meaningful work within a community that sustains a worker's inner life with self-expression as a significant enabling concept. Overall, responses suggest that, regardless of age and religion, employees are desirous for their inner spiritual needs (such as meaningful work and social impact) to be met by the organisation. It is within organisational policy guidance that employee needs can be met (Alexander et al., 2021). However, data suggest that generational and religious groupings were unaware of organisational support for their spiritual needs and, in turn, may feel unable to express their spiritual needs at work. Thus, in line with Digh (1999) and Miller and Ewest's (2015) faith-safe modality, spirituality is invariably'tolerated' in the workplace.

In conclusion, individuals bring their whole selves to the workplace and aspire for meaningful work that coalesces with their spiritual values and inner life needs. Although these needs vary by generational and religious groupings, the central principles remain unchanged. Organisational policy and procedures guide managers and employees towards their organisational values. However, if an organisation wishes its employees to live out their values, they need to equally ascribe to their values (Smola \& Sutton, 2002). HR strategies that merely anchor and mirror individual and organisational values, do not go far enough (Iqbal \& Hassan, 2016). A cohesive approach that utilises a mutually agreed spirituality policy, which matches organisational practice, can encourage greater tolerance of differences, and benefit at both individual and societal level (Woolf, 2020). However, caution is needed, since policyrich organisations risk becoming 'nanny state' ambassadors, with the capacity to divide as well as unite. Thus, at a minimum, there is a need to create a working environment that is conducive to and fosters self-expression. 
Overall, whilst it is possible to enhance organisational performance (Mitchell \& Benge, 2015) and make a societal impact through addressing individual spiritual needs, a suite of (mutually agreed) options, much like spirituality itself needs to be considered.

\section{Implications for Practice}

This study makes several contributions to practice. As Finn and Donovan (2013) highlight in the 'Next Gen', supported by Woolf's (2020), 'How we Get Along', policies and procedures underpin a sustainable, inclusive model, wherein values guide behaviour (Sverdlik, 2020). Organisations can introduce spiritual policies that provide horizontal and vertical integration, rather than a disjointed approach which invariably comprises well-intentioned mental health awareness programmes, mental health first aider training, or lunchtime yoga sessions.

The statistically significant responses from across the generations suggests that employees are attracted to organisations that support their personal spirituality, with values being incorporated as practice. However, the study's findings were not universal, with an unexpected result identifying that Christian Baby Boomers had a greater awareness of the work-life programmes offered by their organisation, than were those of Younger generations, who generally perceived work-life balance being of greater importance (Sanchez-Hernandez et al., 2019). Given the lack of homogeneity in employees' spiritual needs, recommend employers need to re-examine work-life balance opportunities for all generations, both to motivate employees and improve productivity (Fry \& Slocum, 2008).

Some more diverse drivers support why workplace spirituality needs to be taken seriously, including increased litigation (Greenwald, 2012), its topical nature (Haldorai et al., 2020) and, in a UK context, to encourage greater tolerance in a diverse workforce (Woolf, 2020). However, as with many initiatives, there is invariably a time lag before practical employer benefits are realised (Forstenlechner \& Al-Waqfi, 2010). Twenty-two years on from Mitroff and Denton's (1999) call for spirituality to be integrated with management, we reiterate that the generation and sustaining of tolerance for spirituality in the workplace can significantly contribute to these turbulent times that organisations face (Vlas, 2017).

\section{Limitations and Direction for Future Researches}

The authors acknowledge that spirituality is a sensitive topic and that given the current study is based on two organisations, no claim for generalisability to all workplaces is being made. The data were drawn from within the UK Retail Sector and a Housing Association, yet even generalisation within these sectors should be taken with extreme caution. There are opportunities, however, for future research to replicate the current study in other sectors, which would extend the findings. The research was deliberately designed with a broad perspective and notwithstanding this pioneering study, questions arose that cannot be addressed by the results alone, although future qualitative research could explore employee perception in greater depth. For example, one specific finding that could be explored through qualitative research is how Muslims of all generations were unaware of any work-life balance programmes. As with any survey instrument, respondents may not have fully grasped the nuances of spirituality as a policy, or associated issues. Furthermore, although the study was grounded in generational theory, the cross-sectional design limits any confidence in inference of causality, although the reported relationships are consistent with our predictions. However, a longitudinal design could seek to address directionality and further illuminate strength of any relationships. In terms of practice, the profound involvement required of employees in expressing their spirituality in the workplace can lead to resistance to change; therefore, future research should consider examining the practical consequences of spirituality at work, particularly in the relationship of personal and organisational values within day-to-day activities. To make a meaningful contribution, future research would be strengthened obtaining objective performance data and benchmark these internal sources with external stakeholders (Schneider et al., 2015).

Open Access This article is licensed under a Creative Commons Attribution 4.0 International License, which permits use, sharing, adaptation, distribution and reproduction in any medium or format, as long as you give appropriate credit to the original author(s) and the source, provide a link to the Creative Commons licence, and indicate if changes were made. The images or other third party material in this article are included in the article's Creative Commons licence, unless indicated otherwise in a credit line to the material. If material is not included in the article's Creative Commons licence and your intended use is not permitted by statutory regulation or exceeds the permitted use, you will need to obtain permission directly from the copyright holder. To view a copy of this licence, visit http://creativecommons. org/licenses/by/4.0/. 


\section{References}

Abdelgawad, S. G., \& Zahra, S. A. (2020). Family firms' religious identity and strategic renewal. Journal of Business Ethics, 163(4), 775-787. https://doi.org/10.1007/s10551-019-04385-4.

ACAS. (2014). Religion or Belief in the Workplace. ACAS.

Alexander, A., De Smet, A., Langstaff, M., \& Ravid, D. (2021). What employees are saying about the future of remote work. McKinsey Quarterly. Retrieved from https://www.mckinsey.com/businessfunctions/organization/our-insights/what-employees-are-sayingabout-the-future-of-remote-work

Amin, S., Situngkir, S., \& Aira, D. (2021). Minimizing workplace deviant behaviors through workplace spirituality and organizational commitment: A case study in Indonesia. Journal of Asian Finance, Economics and Business, 8(5), 1119-1128. https://doi. org/10.13106/jafeb.2021.vol8.no5.1119

Arieli, S., Lilach, S., \& Roccas, S. (2020). Values at work: The impact of personal values in organizations. Applied Psychology, 69(3), 230-275. https://doi.org/10.1111/apps.12181

Ali, A. J. (2010). Islamic challenges to HR in modern organizations. Personnel Review, 39(6), 692-711.

Ashmos, D. P., \& Duchon, D. (2000). Spirituality at work: A conceptualization and measure. Journal of Management Inquiry, 9(1), 134-45.

Badrinarayanan, V., \& Madhavaram, S. (2008). Workplace spirituality and the selling organization: A Conceptual framework and research propositions. Journal of Personal Selling \& Sales Management, 28(4), 421-434.

Barkhuizen, N. (2014). Exploring the importance of rewards as a talent management tool for generation $\mathrm{Y}$ employees. Mediterranean Journal of Social Sciences, 5(27), 1100-1105.

Bauman, Z., \& Haugaard, M. (2008). Liquid modernity and power: A dialogue with Zygmunt Bauman. Journal of Power, 1(2), 111-130.

Bell, E., Bryman, A., \& Harley, B. (2018). Business Research Methods. Oxford: Oxford University Press.

Bell, E., \& Burack, S. (2001). A rumour of Angels: Researching spirituality and work organizations. Academy of Management Proceedings pp 1-7.

Bengtson, V. (2014). Families and Faith: How Religion is Passed Down across Generations Oxford Scholarship Online.

Benson, J., \& Brown, M. (2011). Generations at work: Are there differences and do they matter? The International Journal of Human Resource Management, 22(9), 1843-1865.

Bhatia, S., \& Arora, E. (2017). Workplace spirituality: An employeremployee perspective. International Journal of Innovate Research and Development, 6(1), 106-111.

Bodia, M., \& Ali, H. (2012). Workplace spirituality: A spiritual audit of banking executives in Pakistan. African Journal of Business Management, 6(11), 3888-3897.

Bourne, H., \& Jenkins, M. (2013). Organizational values: A dynamic perspective. Organization Studies, 34(4), 495-514. https://doi. org/10.1177/0170840612467155

Brown, E., Thomas, N., \& Bosselman, R. (2015). Are they leaving or staying: A qualitative analysis of turnover issues for Generation Y hospitality employees with a hospitality education. International Journal of Hospitality Management, 46, 130-137.

Buss, D. (2019). Have Faith: When You Bring Religious Values To Work [Online]. Chief Executive. Retrieved from https://chief executive.net/bring-religious-values-work/. Accessed June 2, 2020.

Cavanagh, G. (1999). Spirituality for managers: Context and critique. Journal of Organizational Change Management, 12(3), 186-199.
CIPD. (2015). Avoiding the Demographic Crunch: Labour Supply and the Ageing Workforce. CIPD.

CIPD. (2020). Profession for the Future [Online]. London: CIPD. Retrieved from https://peopleprofession.cipd.org/. Accessed Feb 4, 2020.

Cowling, R. (2013). B.B.C. Sport: Premier League: How Muslims are changing English football culture [Online]. Retrieved from http://www.bbc.co.uk/sport/0/football/23159023. Accessed on August 28, 2014.

Dahlvig, J., \& Longman, K. (2016). Influences of an evangelical christian worldview on women's leadership development. Advances in Developing Human Resources, 18(2), 243-259.

Deloitte. (2014). Big Demands and High Expectations: The Deloitte Millennial Survey-Executive Summary. Deloitte.

Dewar, C., Hirt, M., \& Keller, S. (2019). The Mindsets and Practices of Excellent CEOs. Chicago: McKinsey \& Company.

Dhingra, N., Samo, A., Schaninger, B., \& Schrimper, M. (2021). Help your employees find purpose - or watch them leave. McKinsey Quarterly. Retrieved from https://www.mckinsey.com/businessfunctions/organization/our-insights/help-your-employees-findpurpose-or-watch-them-leave

Digh, P. (1999). Religion in the Workplace: Make a good-faith effort to accommodate. HR Magazine, 43(13), 84-91.

Driscoll, C., McIsaac, E., \& Wiebe, E. (2019). The material nature of spirituality in the small business workplace: From transcendent ethical values to immanent ethical actions. Journal of Management, Spirituality \& Religion, 16(2), 155-177.

Eisner, S. (2005). Managing Generation Y. SAM Advanced Management Journal, 70(4), 4-15.

Ellor, J. W., \& McFadden, S. H. (2011). Perceptions of the roles of religion and spirituality in the work and lives of professionals in gerontology: Views of the present and expectations about the future. Journal of Religion, Spirituality \& Aging, 23(1/2), 50.

Faragher, J. (2016). Rethinking Age at Work. People Management. London: Chartered Institute of Personnel and Development.

Farmer, M., Allen, S., Duncan, K., \& Alagaraja, M. (2019). Workplace spirituality in the public sector: A study of US water and wastewater agencies. International Journal of Organizational Analysis, 27(3), 441-457.

Field, A. (2018). Discovering Statistics Using IBM SPSS Statistics. Sage.

Finn, D., \& Donovan, A. (2013). PwC's NextGen: A Global Generational Study. PwC.

Generation, Z. (2018, 21 July). We have more to do than drink and take drugs. The Observer.

Finstad, K. (2010). Response interpolation and scale sensitivity: Evidence against 5-point scales. Journal of Usability Studies, 5(3), 104-110.

Fisher, J. (2011). The four domains model: Connecting spirituality, health and well-being. Religious Journal, 2, 17-28.

Forstenlechner, I., \& Al-Waqfi, M. (2010). A job interview for Mo, but none for Mohammed. Religious Discrimination Against Immigrants in Austria and Germany. Personnel Review, 39(6), $767-784$.

Fry, L. (2003). Toward a theory of spiritual leadership. The Leadership Quarterly, 14(6), 693-727.

Fry, L. W., \& Slocum, J. W. (2008). Maximizing the Triple Bottom Line through Spiritual Leadership. Organizational Dynamics, 37(1), 86-96.

Giacalone, R., \& Jurkiewicz, C. (2010). Handbook of Workplace Spirituality and Organizational Performance. New York: M E Sharpe.

Glass, A. (2007). Understanding generation differences for competitive success. Industrial and Commercial Training, 39(2), 98-103. 
Gong, B., Ramkissoon, A., Greenwood, R., \& Hoyte, D. (2018). The generation for change: Millennials, their career orientation, and role innovation. Journal of Managerial Issues, 30(1), 82-86.

Greenwald, J. (2012). Religious discrimination claims rising. Business Insurance, 46(7), 3-18.

Haldorai, K., Kim, W., Chang, H., \& Li, J. (2020). Workplace spirituality as a mediator between ethical climate and workplace deviant behavior. International Journal of Hospitality Management, 86, 102-372. https://doi.org/10.1016/j.ijhm.2019.102372

Jenkin, M. (2015). Millennials want to work for employers committed to values and ethics [Online]. London: Guardian. Retrieved from https://www.theguardian.com/sustainable-business/2015/may/ 05/millennials-employment-employers-values-ethics-jobs. Accessed Sep 21, 2017.

Jurkiewicz, C. L., \& Giacalone, R. A. (2004). A values framework for measuring the impact of workplace spirituality on organizational performance. Personnel Review, 39(6), 767-784.

Iqbal, Q., \& Hassan, S. (2016). Role of workplace spirituality: Personality traits and counterproductive workplace behaviors in banking sector. International Journal of Management, Accounting and Economics, 3(12), 806-821.

Karakas, F. (2010). Spirituality and performance in organizations: A literature review. Journal of Business Ethics, 94(1), 89-106.

Khaled, M. T., Banyhamdan, H. H., \& AMohi-Adden, Y. A. (2012). Transforming an organization into a spiritual one: A fivepathway integrated Framework. International Journal of Business and Management, 7(11), 74-83.

Kibui, A., Gachunga, H., \& Namusonge, G. (2014). Role of talent management on employees retention in Kenya: A survey of state corporations in Kenya: Empirical review. International Journal of Science and Research, 3(2), 414-424.

Knight, R. (2014). Managing People from 5 Generations [Online]. Harvard Business Review. Retrieved from https://hbr.org/2014/ 09/managing-people-from-5-generations Accessed on Sep 21, 2017.

Kourie, C. (2006). The "Turn" to spirituality. Journal of Acta Theologica Supplementum, 8(1), 19-38.

Kumar, P. (2014). Managing career aspirations of generation $\mathrm{Y}-\mathrm{a}$ key to business excellence. Global Journal of Multidisciplinary Studies, 3(5), 101-112.

Lancaster, L. (2003). The click and clash of generations. Library Journal Archive Content, 128, 37.

Lund, D., Fornaciari, C., \& McGee, J. (2003). Research in spirituality, religion and work: Walking the line between relevance and legitimacy. Journal of Organizational Change Management, 16(4), 378-395.

Lyons, S. T., \& LeBlanc, J. E. (2019). Generational Identity in the Workplace: Toward Understanding and Empathy. Cheltenham, Gloucestershire, Edward Elgar Publishing Limited.

Madden, T. (2015). Journeys of purpose: A review of literature about work and spirituality. The International Journal of Religion and Spirituality, in: Society, 5(4), 1-12.

Manneheim, K. (1936). The problem of generations. In P. Kecskemeti (Ed.), Essays on the Sociology of Knowledge (p. 276). Abindon: Routledge.

McGhee, P. (2019). Integrating christian spirituality at work: combining top-down and bottom-up approaches. Religions, 10, 433.

Miller, D., \& Ewest, T. (2013). The present state of workplace spirituality: A literature review considering context, theory, and measurement/assessment. Journal of Religious \& Theological Information, 12(1-2), 29-54.

Miller, D., \& Ewest, T. (2015). A new framework for analyzing organizational workplace religion and spirituality. Journal of Management, Spirituality \& Religion, 12(4), 305-328.
Milliman, J., Czaplewski, A. J., \& Ferguson, J. (2003). Workplace spirituality and employee work attitudes: An exploratory empirical assessment. Journal of Organizational Change Management, 16(4), 426-447.

Mir, U., Hassan, S., \& Egel, M. (2019). An integrated framework for organizational performance enhancement through spirituality. Journal of the Research Society of Pakistan, 36(2), 233-243.

Mitchell, M., \& Beninger, K. (2015). Religion or belief in the workplace and service delivery-Findings from a call for evidence. London: NatCen Social Research. Equality and Human Rights Commission.

Mitroff, I., \& Denton, E. (1999). A Study of Spirituality in the Workplace. Sloan Management Review.

Morgan, J. (2005). Religion at work: A legal quagmire. Managerial Law, 47(3/4), 247-259.

Mukherjee, S., Bhattacharjee, S., \& Singha, S. (2016). Workplace spirituality: A paradigm shift to ethics from business. IOSR Journal of Business and Management, 1, 11-15.

Neal, J., Lichtenstein, B., \& Banner, D. (1999). Spiritual perspectives on individual, organizational and societal transformation. Journal of Organizational Change Management, 12(3), 175-186. https://doi.org/10.1108/09534819910273757.

Neal, J. (2018). Overview of workplace spirituality research. In S. Dhiman, G. Roberts, \& J. Crossman (Eds.), The Palgrave Handbook of Workplace Spirituality and Fulfilment. CA, USA: Springer International Publishing.

Palframan, J., \& Lancaster, T. (2019). Workplace spirituality and person-organization fit theory: development of a theoretical model. Journal of Human Values, 25(3), 133-149.

Perry, E. L., Hanvongse, A., \& Casoinic, D. A. (2013). Making a case for the existence of generational stereotypes: A literature review and exploratory study. In J. Field, R. J. Burke, \& C. L. Cooper (Eds.), The Sage Handbook of Aging, Work and Society (pp. 416-442). Sage.

Petrucelli, T. (2017). Winning the "cat-and-mouse game" of retaining millennial talent. Strategic HR Review, 16(1), 42-44.

Pew Research Center. (2015). The Future of World Religions: Population Growth Projections, 2010-2050. Numbers Facts and Trends Shaping the World. Washington: Pew Research Center.

Pew Research Center. (2010). Religion Among the Millenials. Pew Forum on Religion \& Public Life.

Richards, P. S., Bartz, J. D., \& O'Grady, K. A. (2009). Assessing religion and spirituality in counselling: Some reflections and recommendations. Counselling and Values, 54(1), 65-79.

Robinson, D. (2009). Christianity and Islam Do Not Share Values [Online]. Gale. http://ic.galegroup.com/ic/ovic/ViewpointsDe tailsPage/DocumentToolsPortletWindow?displayGroupName= Viewpoints\&jsid=2f6b3377e7acca7414e05c44fe97e8e5\&ac tion $=2 \&$ catId $=\&$ documentId $=$ GALE\%7CEJ3010110277\&u= high63991\&zid=44157e4e22adcab99fc3451cc8c07dc4. Accessed Sep 20, 2017.

Royal College of Psychiatrists. (2014). Spirituality and mental health [Online]. London: The Royal College of Psychiatrists. http:// www.rcpsych.ac.uk/mentalhealthinformation/therapies/spirituali tyandmentalhealth.aspx. Accessed Oct 24, 2017.

Saks, A. M. (2011). Workplace spirituality and employee engagement. Journal of Management, Spirituality \& Religion, 8(4), 317-340.

Sanchez-Hernandez, M., Gonzalez-Lopez, O. P., Buenadicha-Matios, M., \& Tato-Jimenez, J. (2019). Work-life balance in great companies and pending issues for engaging new generations at work. International Journal of Environmental Research and Public Health, 16, 5122.

Sauerwein, J. (2017). The intersection of religiosity, workplace spirituality and ethical sensitivity in practicing accountants. Journal of Religion and Business Ethics, 3, 4. 
Schroer, W. (2015). Generations X,Y, Z and the Others [Online]. The Social Librarian. Retrieved from http://www.socialmarketing. org/newsletter/features/generation3.htm Accessed Nov 24, 2015.

Sedikides, C. (2010). Why does religiosity persist? Personality and Social Psychology Review, 14(1), 3-6.

Shinde, U., \& Fleck, E. (2015). What spirituality can bring to leaders and managers: Enabling creativity, empathy and a stress free workplace. Journal of Organizational Psychology, 15(1), 101-110.

Simpson, B. (2020). Leading with purpose and humanity: A conversation with Hubert Joly. Retrieved from https://www. mckinsey.com/ /media/McKinsey/Business\%20Functions/Strat egy $\% 20$ and $\% 20$ Corporate\%20Finance/Our\%20Insights/Lead ing $\% 20$ with $\% 20$ purpose $\% 20$ and $\% 20$ humanity $\% 20 \mathrm{~A} \% 20$ conver sation $\% 25$ purpose-and-humanity-a-conversation-with-HubertJoly-vF.pdf.

Smola, K. W., \& Sutton, C. D. (2002). Generational differences: Revisiting generational work values for the new millennium. Journal of Organizational Behavior, 23(SpecIssue), 363-382. https://doi.org/10.1002/job.147

Sverdlik, N. (2020). Religiosity and the value of being moral: Understanding the meaning of morality through a personal values perspective. European Journal of Social Psychology, $50(2), 406-422$.

Schwartz, S. H., et al. (2012). Refining the theory of basic individual values. Journal of Personality and Social Psychology, 103(4), 663-688.

Tulgan, B. (2011). Generation Y. Journal of Leadership Studies, 5(3), 77.

Twenge, J. M., Exline, J. J., Grubbs, J. B., Sastry, R., \& Campbell, W. K. (2015). Generational and time period differences in American Adolescents' Religious Orientation, 1966-2014. PLOS ONE. https://doi.org/10.1371/journal.pone.0121454

You, J., Kim, S., Kim, K., Cho, A., \& Chang, W. (2021). Conceptualizing meaningful work and its implications for HRD. European Journal of Training and Development, 45(1), 36-52. https://doi.org/10.1108/EJTD-01-2020-0005

Urick, M. J., et al. (2016). Understanding and Managing Intergenerational Conflict: An Examination of Influences and Strategies. Work, Aging and Retirement, 3(2), 166-185.
Vlas, N. (2017). Is Religion inherently violent? Religion as a threat and promise for the Global Security. Politics and Religion Journal, 4(2), 297-314.

Vveinhardt, J. (2017). Congruence of Personal and Organizational Values. Singapore: IntechOpen.

Wagner-Marsh, F., \& Conley, J. (1999). The fourth wave: The spiritually-based firm. Journal of Organizational Change Management, 12(4), 292-301.

Wallace, J. E. (2006). Work commitment in the legal profession: A study of Baby Boomers and Generation Xers. International Journal of the Legal Profession, 13(2), 137-151. https://doi.org/ 10.1080/09695950600961293.

Weber, J. (2017). Discovering the Millennials' personal values orientation: a comparison to two managerial populations. Journal of Business Ethics, 143(3), 517-529.

Weber, J., \& Elm, D. (2018). Exploring and comparing cognitive moral reasoning of Millennials and across multiple generations. Business and Society Review, 123(3), 415-458.

Weller, P., Feldman, A., \& Purdman, K. (2001). Religious Discrimination in England and Wales. Home Office Research Study 220. London: Home Office.

Wimbush, J., \& Shepard, J. (1994). Toward an understanding of ethical climate: Its relationship to ethical behavior and supervisory influence. Journal of Business Ethics, 13(8), 637-647.

Woolf Institute. (2020). How We Get Along (p. 115). London: Woolf Institute.

Young, J. (2020). That's the spirit: the value of workplace spirituality [Online]. London: CIPD. Retrieved from https://www.cipd.co. uk/news-views/changing-work-views/future-work/thoughtpieces/workplace-spirituality. Accessed 9 June 2020.

Young, S. (2007). Comparing best practice cases in creating an environmental conductive to development benefits. Growth and Investments: Developing Case Study Methodology, 1(1), 1-10.

Zohar, D., \& Marshall, I. (2004). Spiritual Capital: Wealth We Can Live By. Bloomsbury.

Publisher's Note Springer Nature remains neutral with regard to jurisdictional claims in published maps and institutional affiliations. 